4. Про затвердження Порядку стажування громадян з числа молоді в апараті Державної міграційної служби України: наказ Міністерства внутрішніх справ України від 02.05.2018 N 353. URL: https://zakon.rada.gov.ua/laws/show/z0622-18\#Text (дата звернення: 26.02.2021).

DOI https://doi.org/10.30525/978-9934-26-045-2-30

\title{
ЄВРОПЕЙСЬКІ ІНСТРУМЕНТИ ДЛЯ НАЦІОНАЛЬНОЇ СИСТЕМИ КВАЛІФІКАЦІЙ
}

\author{
Семигіна T. B. \\ доктор політичних наук, професорка \\ Академії праиі, сочіальних відносин і туризму \\ м. Київ, Украӥна
}

Україна взяла на себе зобов'язання гармонізувати свою політику щодо професійних кваліфікацій з політикою Європейського Союзу, створити національні механізми з метою визнання кваліфікацій та компетентностей 3 урахуванням європейського досвіду. Впровадження такої політики має на меті розвиток професійної мобільності, як вертикальної, так і горизонтальної, за рахунок механізму офіційного визнання повних або часткових кваліфікацій, набутих у системі формальної чи неформальної освіти в Україні та за ії межами, формування в українському суспільстві розуміння цінності навчання впродовж життя, яке дозволяє набувати нових кваліфікацій, що мають попит на ринку праці [1]. Наразі стратегія «Європа 2020» [5] наголошує на сталому розвиткові навичок, вмінь та кваліфікацій задля досягнення економічного зростання і зайнятості.

Ця робота має на меті розкрити ті механізми публічного управління, які використовуються у європейському регіоні для забезпечення прозорості, зіставлення та визнання кваліфікацій у межах відповідної політики.

Зауважимо насамперед, що в європейських країнах «кваліфікація» тлумачиться як «офіційний результат процесу оцінювання та перевірки, який отримується, коли компетентний орган визначає, що особа досягла результатів навчання відповідно до заданих стандартів» [7]. Це визначення виразно прив'язує кваліфікацію до стандартів (освітніх чи 
професійних), i встановлює, що певні органи мають перевіряти отримані особою результати навчання, оцінювати їх та забезпечувати офіційне визнання.

Ключовим європейським інструментом щодо кваліфікацій, який надає змогу поєднати ринок освітніх послуг з ринком праці, можна вважати ESCO (European Skills, Competences, Qualifications and Occupations) [3], багатомовний класифікатор європейських навичок, компетенцій, кваліфікації та професій. Ця загальнодоступна онлайн база даних містить описи майже трьох тисяч професій і майже 14 тисяч навичок, пов'язаних із цими професіями, перекладена на 27 мов; вона грунтується на Міжнародній стандартній класифікації професій (International Standard Classification of Occupations, ISCO), яку веде Міжнародна організація праці.

ESCO має три основні компоненти: 1) професії (рід занять); 2) знання, навички та компетентності; 3) кваліфікації. Кожне поняття, вміщене в базі, пов'язане 3 щонайменше одним терміном на всіх мовах ESCO. У багатьох випадках наявні кілька термінів для позначення одного і того ж або подібних понять. Класифікатор постійно оновлюється і трансформує свій функціонал.

Класифікатор ESCO поєднує ринок праці i ринок освітніх послуг, адже, з одного боку, сприяє кращому розумінню надавачами освітніх послуг потреб ринку праці та адаптації освітніх програм до цих вимог, а з іншого боку - допомагає роботодавцям сприйняти результати навчання, набуті тими, хто шукає роботу. Цією базою користуються як роботодавці, які бажають знайти потрібних працівників, так і шукачі роботи, які прагнуть віднайти належні робочі місця для своїх навичок [3].

Крім того, класифікатор ESCO слугує основою для створення «паспорту набутих компетентностей» і використовується у кількох ініціативах Європейської Комісії у сфері навичок та кваліфікацій, спрямованих на підвищення прозорості ринку праці та освітніх систем, зокрема у проєкті Europass (Свропас або Європаспорт) [4], пан'європейській базі даних щодо кваліфікацій. Europass пропонує безкоштовні послуги тим, хто створює собі профіль Europass, зокрема, послуги щодо створення структурованого резюме (воно, приміром, потрібне для програм мобільності студентів), пошуку вакансій, фіксування волонтерського досвіду, документів, що підтверджують професійні кваліфікації, тощо. Завдяки цифровим документам Europass учні та студенти, роботодавці, заклади освіти і професійної підготовки, а також інші уповноважені органи мають простий та надійний спосіб перевірки достовірності цифрових документів. 
У державах-членах $\mathrm{CC}$ та в країнах, які $є$ кандидатами в члени $\mathrm{CC}$, створені Національні центри Europass. Станом на початок 2021 року функціонує 36 національних центрів Europass; мережу цих центрів координує Європейська Комісія. Національні центри Europass забезпечують підтримку користувачів і відповідають за сертифікацію рівня освіти дорослих, координують усі заходи, пов'язані з документами Europass. Центри також відіграють опосередковану роль у підтримці європейських політичних розробок, пов'язаних із прозорістю компетентностей та кваліфікацій [4].

До одного 3 найважливіших інструментів загальноєвропейської політики щодо кваліфікацій можна віднести рамки кваліфікацій, тобто цілісний структурований опис кваліфікаційних рівнів, через який можуть бути виражені та співвіднесені між собою в узгоджений спосіб усі кваліфікації у певній системі кваліфікацій. Рамки кваліфікацій визначають результати навчання, виражені в термінах компетентностей, для кваліфікацій певних рівнів. Нині на загальноєвропейському просторі співіснують дві метарамки кваліфікацій: 1) European Qualifications Framework for lifelong learning, EQF LLL/EQF (Свропейська рамка кваліфікацій для навчання впродовж життя, СРК) [7]; 2) Framework for Qualifications of the European Higher Education Area, FQ EHEA (Рамка кваліфікацій Свропейського простору вищої освіти).

СРК надає загальний опис восьми прийнятих у Європейському Союзі кваліфікаційних рівнів. Кожний із восьми рівнів визначений набором дескрипторів, що відображують результати навчання (навчальні результати), притаманні кваліфікаціям цього рівня, у термінах знань, умінь, відповідальності та автономності. При цьому ЄРК описує усі можливі рівні кваліфікацій на відміну від Рамки кваліфікацій Європейського простору вищої освіти, яка відображує результати навчання тільки для кваліфікацій вищої освіти.

Європейські країни, спираючись на загальноєвропейські метарамки, розробляють національні рамки кваліфікацій (НРК), а також методики віднесення освітніх та професійних кваліфікацій до певного рівня НРК, забезпечення зв'язку між професійними стандартами, стандартами освіти та рівнями НРК. Свропейська Комісія визначила виразні критерії та процедури зіставлення СРК та НРК, діяльності Національних координаційних пунктів, подання національної доповіді щодо зіставлення СРК та НРК. Станом на 2020 рік національні рамки кваліфікацій затверджені у 38 країнах [6].

Європейські інструменти політики щодо кваліфікацій також включають механізми взаємовизнання освітніх i професійних кваліфікацій. Для цього, починаючи з 1994 р. діє Європейська мережа 
інформаційних центрів (The European Network of National Information Centres, ENIC Network), яка станом на 2021 р. має 54 члени, а в європейських країнах створюють Національні інформаційні центри академічної мобільності (National Academic Recognition Information Centres, NARIC). Зараз інституції Європейського Союзу працюють над запровадженням механізмів автоматичного визнання кваліфікацій у мережі ENIC-NARIC [2].

Таким чином, у європейському просторі не лише ухвалена політика щодо взаємовизнання освітніх та професійних кваліфікацій, а й використовують сучасні інструменти реалізації цієї політики, які дають змогу порівнювати кваліфікації та їхнє наповнення, фіксувати та відстежувати результати навчання, робити процес визнання кваліфікацій зручним та прозорим.

В Україні у 2020 р. нарешті ухвалена така Національна рамка кваліфікацій, яка відповідає СРК. Багато років діє Національний центр академічної мобільності (його функції зараз покладені на державне підприємство «Інформаційно-іміджевий центр» Міністерства освіти i науки України); 32014 р. заклади освіти отримали право визнання освітніх кваліфікацій для тих, хто вступає до них. Проте в Україні немає ані координаційного центру Europass, ані національного координаційного центру, який би займався питаннями самосертифікації НРК. Україна послуговується Державним класифікатором професій, який видається застарілим за своєю суттю, формою та регуляторним спрямуванням, далеким від принципів побудови класифікатора-довідника ESCO, орієнтованого на кінцевих споживачів, а не на потреби державних регуляторів. Впровадження в Україні національних механізмів визнання кваліфікацій 3 урахуванням сучасного європейського досвіду потребує критичного переосмислення поточної вітчизняної державної політики щодо кваліфікацій і активнішого приєднання до загальноєвропейських інформаційних механізмів публічного управління.

\section{Література:}

1. Семигіна, Т. В., Баланюк, Ю. В. Розвиток в Україні механізмів державного регулювання системи професійних кваліфікацій // The system of public administration in the context of decentralization of power. Riga: Baltija Publishing, 2020. C. 129-146.

2. About the ENIC-NARIC Networks. URL: https://www.enic-naric.net (дата звернення: 05.03.2021).

3. ESCO / European Commission. URL: https://ec.europa.eu/esco (дата звернення: 2.03.2021). 
4. Europass / European Union. URL: https://europa.eu/europass/en (дата звернення: 2.03.2021).

5. Europe 2020. A European strategy for smart, sustainable and inclusive growth / European Commission, 2010. URL: https://ec.europa.eu/ eu2020 (дата звернення: 28.02.2021).

6. National qualifications frameworks (NQFs) / CEDEFOP. URL: https://www.cedefop.europa.eu/en/events-and-projects/projects/national-qualifications-framework-nqf (дата звернення: 22.02.2021).

7. Recommendation on the European Qualifications Framework for lifelong learning and repealing the recommendation of the European Parliament and of the Council of 23 April 2008 on the establishment of the European Qualifications Framework for lifelong learning / The Council of the European Union, 2017. URL: https://eur-lex.europa.eu/legalcontent/EN/TXT/?uri=CELEX\%3A32017H0615(01) (дата звернення: 02.03.2021).

DOI https://doi.org/10.30525/978-9934-26-045-2-31

\title{
ТРАНСФОРМАЦІЯ ДЕРЖАВНОЇ ВЛАДИ ТА ПРОБЛЕМА КОМПЕТЕНТНОСТІ ӤЇ СУБ'ЄКТІВ
}

\author{
Ситник Г. П. \\ orcid.org/0000-0002-3083-5733
}

доктор наук з державного управління, професор, професор кафедри державного управління

Київського начіонального університету імені Тараса Шевченка

\author{
Штельмашенко А. Д. \\ orcid.org/0000-0002-7998-3729 \\ кандидат політичних наук, \\ асистент кафедри державного управління
}

Київського національного університету імені Тараса Шевченка м. Київ, Украӥна

Очевидно, що осмислення тієї чи іншої інформації щодо життєдіяльності людини (індивіда), суспільства та соціальних інститутів змінює як суспільство, так і його ставлення до державної влади. Донедавна джерелами отримання та здійснення вказаної влади передусім були сила (інститути організованого насильства) та 